\title{
HUBUNGAN NILAI UJIAN NASIONAL (NUN) MATA PELAJARAN MATEMATIKA SMP DENGAN HASIL BELAJAR SISWA PADA MATA PELAJARAN MEKANIKA TEKNIK PROGRAM KEAHLIAN GAMBAR BANGUNAN KELAS XI DI SMK NEGERI 35 JAKARTA BARAT
}

\author{
Fitri Rahmawati, Tuti Iriani ${ }^{* *}$, Santoso Sri Handoyo. ${ }^{3}$ \\ ${ }^{1}$ Alumni Pendidikan Teknik Bangunan, FT UNJ, Jakarta, Indonesia. \\ 2 Pendidikan Teknik Bangunan, FT UNJ, Jakarta, Indonesia. \\ ${ }^{3}$ Pendidikan Teknik Bangunan, FT UNJ, Jakarta, Indonesia \\ *Corresponding author: tutiiriani@unj.ac.id, santoso_handoyo@unj.ac.id
}

\begin{abstract}
This study aims to determine the relation of National Exam Value in junior Mathematics courses with student learning outcomes in Engineering Mechanics Course at class XI majoring in drawing technique building academic year 2013/2014 SMK Negeri 35 Jakarta. The research lasted for 3 months from October to December 2014.

The located of research was conducted at SMK Negeri 35 Jakarta. The population in this study were students of class XI academic year 2013/2014 majoring in engineering drawings are 51 people. The method used in this study is a method of ex post facto to obtain primary data for the variables $Y$ and secondary data from National Exam Value for the variable $X$, the approach used is one shot model to research correlational. Trial questionnaire instrument conducted by 20 respondents majoring in engineering drawing class $X I$ buildings. After the test phase results obtained valid, the number of items valid statement after test instruments is 30 statement items.

Data analysis techniques starts with finding the simple linear regression equation $\hat{Y}=1,78+0,73 X$. While testing requirements analysis is to test the normality of the estimated regression error $X$ over $Y$ with Liliefors test produces a maximum of 0,119 whereas $L$ count, Ltable on stage at significance level ( $\alpha$ ) of 0,05 obtained a value of 0,124 then obtained Lcount < Ltable or $0,119<0,124$ thus it can be concluded that the estimated regression error $X$ over $Y$ is normally distributed. Significance of correlational test with correlation Product Moment formula the result coefficient correlation maximum 0,94, which means that there is a relationship between independent variable $X$ with the dependent vriable $Y$. followed by testing the significance of correlation produces that (tcount $=19,29)>($ ttable $=1,67)$ at $\alpha=0,05$ with $d k=49$, This buffer is concluded that there is a relationship with the Junior National Exam Value learning outcomes Engineering Mechanics.
\end{abstract}

Keywords : Relationship National Examination Subjects Mathematics Junior, Learning Outcomes Engineering Mechanics. 


\section{PENDAHULUAN}

Siswa Sekolah Menengah Pertama (SMP) pada dasarnya dikembangkan dan diarahkan untuk menjadi calon siswa pada Sekolah Menengah Atas (SMA) dan Sekolah Menengah Kejuruan (SMK). SMK diharapkan dapat mencetak peserta didiknya dalam memasuki dunia kerja dengan berbekal ilmu pengetahuan dan keahlian.

Untuk SMK khususnya jurusan Teknik Gambar Bangunan menyajikan mata pelajaran antara lain pelajaran Mekanika Teknik. Mekanika Teknik merupakan pelajaran yang wajib diikuti oleh siswa di teknik gambar bangunan yang berisi substansi perhitungan tentang perencanaan struktur bangunan seperti perhitungan gaya-gaya yang bekerja pada bangunan baik gaya luar maupun gaya dalam, melakukan analisis pada struktur bangunan, serta mendesain dan merancang bangunan yang efisien. Untuk menguasai mata pelajaran ini siswa harus mempunyai dasar kemampuan yang baik di mata pelajaran Matematika.

Kemampuan dasar yang diperoleh siswa untuk bekal kelanjutan belajar ke SMK, diperoleh di SMP asal yang dinyatakan dalam daftar NUN yang juga merupakan perangkat untuk seleksi penerimaan siswa baru. Pada SMP ada beberapa mata pelajaran yang di Ujian Nasionalkan diantaranya Bahasa Indonesia, Bahasa Inggris, IImu Pengetahuan Alam, dan Matematika. Matematika merupakan ilmu pengetahuan yang berhubungan dengan perhitungan-perhitungan yang dapat dipergunakan dalam kehidupan sehari-hari serta bekal untuk melanjutkan kejenjang pendidikan yang lebih tinggi dalam mempelajari pelajaran yang berkaitan dengan perhitungan seperti pelajaran Mekanika Teknik.

Bila ditinjau dari materi yang dipelajari pada Mekanika Teknik berdasarkan data nilai Mekanika Teknik yang diperoleh di SMK Negeri 35 Jakarta Barat dengan nilai Kriteria Ketuntasan Minimal (KKM) 76 tahun ajaran 2013 / 2014 terdapat 55 \% siswa yang mendapatkan nilai dibawah KKM dengan ratarata nilai 72 . Maka dari itu diduga bahwa pemahaman tentang perhitungan Matematika yang berperan sebagai kemampuan dasar menghitung dalam menyelesaikan soal-soal perhitungan masih rendah, yang seharusnya sudah cukup memadai dalam mengaplikasikan pelajaran Mekanika Teknik karena sudah diberikan semenjak kelas VII sampai kelas IX. Sehingga NUN Matematika SMP yang dipilih sebagai tolak ukur dalam keberhasilan pelajaran Mekanika Teknik.

Berdasarkan pemaparan di atas, penelitian ini akan mengkaji hubungan mata pelajaran Matematika di SMP dengan mata pelajaran di SMK. Mata pelajaran yang akan diambil sebagai objek penelitian adalah mata pelajaran Mekanika Teknik kelas XI untuk dianalisis apakah ada hubungannya dengan nilai Matematika NUN SMP nya

Hasil belajar merupakan bagian terpenting dalam pembelajaran. Dimyati dan Mudjiono (2002) mendefinisikan hasil belajar merupakan hasil yang dicapai dalam bentuk angka-angka atau skor setelah diberikan tes 
hasil belajar pada setiap akhir pembelajaran.

Sementara menurut Mulyasa (2008) hasil belajar merupakan prestasi belajar siswa secara keseluruhan yang menjadi indikator kompetensi dan derajat perubahan prilaku yang bersangkutan. Adapun pendapat lain pengertian hasil belajar menurut Nana Sudjana (2011) hasil belajar adalah kemampuan-kemampuan yang dimiliki siswa setelah ia menerima pengalaman belajarnya.

Untuk mengukur hasil belajar siswa, dapat dilakukan dengan melalui tes formatif dan tes sumatif. Tes formatif adalah kegiatan penilaian yang bertujuan untuk mencari umpan balik atau feedback, yang selanjutnya hasil penilaian tersebut dapat digunakan untuk memperbaiki proses belajar-mengajar yang sedang atau yang sudah dilakasanakan. Penilaian formatif tidak hanya berbentuk tes tertulis dan hanya dilakukan pada setiap akhir pelajaran, tetapi dapat pula berbentuk pertanyaan-pertanyaan lisan atau tugas-tugas yang diberikan selama pelajaran berlangsung ataupun sesudah pelajaran selesai. (Ngalim, 2009).

Sementara tes sumatif menurut Ngalim (2009) adalah penilaian yang dilakukan untuk memperoleh data atau informasi sampai dimana penguasaan belajar siswa terhadap bahan pelajaran yang telah dipelajarinya selama jangka waktu tertentu. Adapun fungsi dan tujuannya adalah untuk menentukan apakah dengan nilai yang diperolehnya itu siswa dapat dinyatakan lulus atau tidak lulus. Oleh karena itu, guru sebagai pengajar harus dapat menentukan hasil belajar apa yang dituntut dari siswa setelah proses belajar mengajar berlangsung sesuai dengan waktu yang telah ditetapkan.

Mekanika merupakan cabang ilmu fisika yang mempelajari gerak benda, baik benda yang diam (statika) maupun benda yang bergerak dibawah pengaruh gaya (Tony, 2006). Konsep serta penurunan rumus-rumus secara matematika didalam Mekanika Teknik perlu dipahami dengan baik karena sebagian besar materi yang diberikan adalah metode klasik dengan penyelesaian manual (Eka, 2009). Oleh sebab itu, matematika merupakan salah satu pelajaran yang relevan dengan mata pelajaran mekanika teknik.

Sujono (1988) mengatakan Matematika merupakan bidang studi yang sangat berguna dan banyak memberi bantuan dalam mempelajari berbagai keahlian dan kejuruan. Berdasarkan Peraturan Menteri Pendidikan Nasional No.22 Tahun 2006, mata pelajaran Matematika yang dikutip oleh Lasriany (2013), bertujuan agar peserta didik memiliki: (1) Memahami konsep Matematika, menjelaskan keterkaitan antar konsep dan mengaplikasikan konsep atau algoritma secara luwes, akurat, efisien, dan tepat dalam pemecahan masalah, (2) Menggunakan penalaran pada pola dan sifat, melakukan manipulasi Matematika dalam menjelaskan gagasan dan pernyataan Matematika, (3) Memecahkan masalah yang meliputi kemampuan memahami masalah, merancang model Matematika, menyelesaikan model dan menafsirkan solusi yang diperoleh, 
(4) Mengkomunikasikan gagasan dengan simbol, tabel, diagram, atau media lain untuk memperjelas keadaan atau masalah.

Sesuai dengan tujuan diberikannya Matematika, dapat dilihat bahwa mata pelajaran Matematika memegang peranan sangat penting dalam membantu memahami bidang studi lain serta berperan sebagai alat berpikir untuk memecahkan persoalan-persoalan teknologi, termasuk didalamnya pelajaran Mekanika Teknik

\section{METODE PENELITIAN}

Penelitian ini dilakukan di SMK Negeri 35 Jakarta pada Jurusan Teknik Gambar Bangunan. Waktu penelitian dilaksanakan terhitung dari mulai bulan Oktober 2014 Desember 2014.

Metode yang dipergunakan dalam penelitian ini adalah metode ex post facto dengan desain penelitian yang sistem pendekatannya one shot model yaitu menggunakan satu kali pengumpulan data pada suatu saat untuk keperluan penelitian korelasional. Dalam penelitian ini peneliti tidak mengontrol salah satu variabel dan tidak dapat dimanipulasi karena variabel itu telah ada sebelumnya, sedangkan untuk data yang lain diperoleh dengan mengadakan tes.

Populasi dalam penelitian ini adalah siswa kelas XI Jurusan Teknik Gambar Bangunan tahun akademik 2013-2014 di SMK Negeri 35 Jakarta yang berjumlah 51 orang. Teknik pengambilan sampel yang digunakan adalah teknik Purposive Sampling yaitu yang telah mengikuti pelajaran Mekanika Teknik, maka penulis menggunakan seluruh jumlah populasi untuk dijadikan sampel. Pada penelitian ini yang menjadi variabel bebas (X) adalah Nilai Ujian Nasional Matematika di SMP, sedangkan variabel terikatnya (Y) adalah Hasil belajar Mekanika Teknik. Teknik pengumpulan data menggunakan teknik dokumentasi dan teknik tes untuk memperoleh data hasil belajar mata pelajaran Mekanika Teknik. Penelitian ini menggunakan instrument tes objektif berbentuk pilihan ganda. Dalam menentukan kualitas instrumen, maka instrumen tersebut harus diketahui validitas dan reliabilitasnya.

Dalam menghitung validitas dari setiap item pada soal Mekanika Teknik menggunakan rumus Product Moment. Diketahui jumlah $n$ pada uji coba adalah 20 pada taraf signifikan 0,05 didapat nilai rtabel sebesar 0,444 . Setelah itu dilakukan analisis hasil coba. Hasil yang di dapat dari 30 item pernyataan, terdapat 4 item yang drop. Sedangkan untuk uji realibilitas, berdasarkan hasil perhitungan manual (rumus Alpha) dan dengan menggunakan SPSS versi 16 diperoleh nilai reliabilitas sebesar 0,754 . Dengan nilai sebesar 0,754 mengindikasikan bahwa reliabilitas tersebut tergolong tinggi yang memiliki arti ketika angket tersebut di uji cobakan dalam waktu yang berbeda, maka akan menunjukkan hasil yang relatif sama.

Teknik analisis data pada penelitian ini dilakukan pengujian dengan menggunakan uji normalitas, dan uji linearitas. Uji normalitas 
digunakan untuk mengetahui data sampel yang digunakan berasal dari populasi yang berdistribusi normal atau tidak, sedangkan uji linearitas digunakan untuk menguji bentuk regresinya. Kemudian dilakukan uji analisis data untuk mengetahui hubungan antara variabel bebas dengan variabel terikat, dengan cara menghitung koefisien korelasi menggunakan rumus Korelasi Product Moment dari Pearson's dan uji keberartian korelasi.

\section{HASIL PENELITIAN dan PEMBAHASAN}

a. Skor Jawaban Responden Pada Soal Mekanika Teknik

Hasil belajar Mekanika Teknik setelah hasil tes pengujian yang pertama dan kedua dirata-ratakan menunjukan skor tertinggi 8,16, skor terendah 4,5, standar baku 1,04 dan rata-rata $(\bar{Y})$ nilai 6,67 . Frekuensi data hasil belajar Mekanika Teknik dapat dilihat pada tabel 1 .

Tabel 1. Distribusi Frekuensi Penelitian Hasil Belajar Mekanika Teknik

\begin{tabular}{|c|c|c|c|c|}
\hline Interval Nilai & Titik Tengah & Batas Nyata & F Absolut & F Relatif (\%) \\
\hline $4,5-5,02$ & 4,76 & 4,49 & 4 & 7,84 \\
\hline $5,03-5,55$ & 5,29 & 5,02 & 7 & 13,72 \\
\hline $5,56-6,08$ & 5,82 & 5,55 & 4 & 7,84 \\
\hline $6,09-6,61$ & 6,35 & 6,08 & 6 & 11,76 \\
\hline $6,62-7,14$ & 6,88 & 6,61 & 10 & 19,60 \\
\hline $7,15-7,67$ & 7,41 & 7,14 & 9 & 17,64 \\
\hline $7,68-8,2$ & 7,94 & 7,67 & 11 & 21,56 \\
\hline$\Sigma$ & - & - & 51 & $100,00 \%$ \\
\hline
\end{tabular}

Berdasarkan nilai skor rata-rata hasil belajar Mekanika Teknik (test) yaitu sebesar 6,67, maka diperoleh 21 responden atau sekitar $41 \%$ responden berada dibawah kelompok rata-rata, 10 responden atau sekitar $20 \%$ responden berada dalam kelompok rata-rata, 20 responden atau sekitar $39 \%$ responden berada diatas kelompok rata-rata. b. Nilai Ujian Nasional Matematika

Nilai Ujian Nasional Matematika Tahun Akademik 2013/2014 siswa kelas XI Jurusan Teknik Gambar Bangunan SMK Negeri 35 Jakarta Barat diperoleh nilai skor tertinggi 9,5, skor terendah 5,75, simpangan baku 0,7 dan rata-rata $(\overline{\mathrm{Y}}) 6,71$. Frekuensi data NUN Matematika dapat dilihat pada tabel 2.

Tabel 2. Distribusi frekuensi NUN Matematika

\begin{tabular}{|c|c|c|c|c|}
\hline Interval Nilai & Titik Tengah & Batas Nyata & F Absolut & F Relatif (\%) \\
\hline $5,75-6,28$ & 6,01 & 5,74 & 17 & 33,33 \\
\hline $6,29-6.82$ & 6,55 & 6,28 & 18 & 35,29 \\
\hline $6,83-7,36$ & 7,09 & 6,82 & 8 & 15,68 \\
\hline $7,37-7,9$ & 7,63 & 7,36 & 4 & 7,84 \\
\hline
\end{tabular}




\begin{tabular}{|c|c|c|c|c|}
\hline Interval Nilai & Titik Tengah & Batas Nyata & F Absolut & F Relatif (\%) \\
\hline $7,91-8,44$ & 8,17 & 7,90 & 1 & 1,96 \\
\hline $8,45-8,98$ & 8,71 & 8,44 & 2 & 3,92 \\
\hline $8,99-9,52$ & 9,25 & 8,98 & 1 & 1,96 \\
\hline$\Sigma$ & - & - & 51 & $100,00 \%$ \\
\hline
\end{tabular}

Berdasarkan rata-rata Nilai Ujian Nasional Matematika yaitu sebesar 6,71, maka diperoleh 17 responden atau sekitar $33 \%$ memiliki NUN rendah, 18 responden atau sekitar $35 \%$ memiliki NUN sedang, dan 16 responden atau sekitar $32 \%$ memiliki NUN yang tinggi.

\section{Pembahasan Hasil Penelitian}

Berdasarkan analisis dan hasil pengujian hipotesis yang telah dilakukan didapat data hasil penelitian secara keseluruhan sebagai berikut:

Tabel 3. Data Keseluruhan Penelitian

\begin{tabular}{|l|c|c|c|}
\hline \multicolumn{1}{|c|}{$\begin{array}{c}\text { Perbandingan } \\
\text { Nilai }\end{array}$} & \multicolumn{3}{|c|}{ Hasil } \\
\cline { 2 - 4 } & $t_{\text {hitung }}>t_{\text {tabel }}$ & $\begin{array}{c}\text { Koefisien } \\
\text { Korelasi }\left(r_{x y}\right)\end{array}$ & $\begin{array}{c}\text { Garis Regresi } \\
\text { Linier }\end{array}$ \\
\hline $\begin{array}{l}\text { NUN Matematika } \\
\begin{array}{l}\text { SMP dengan } \\
\text { hasil belajar } \\
\text { Mekanika Teknik }\end{array}\end{array}$ & $7,1>1,67$ & 0,71 & $\hat{Y}=-0,32+1,03 X$ \\
\hline
\end{tabular}

Sesuai tabel 1.3 menunjukkan $t_{\text {hitung }}>t_{\text {tabel }}$ dan korelasi $\left(r_{x y}\right)$ sebesar 0,71 . Sehingga terlihat hubungan positif antara NUN Matematika SMP dengan hasil belajar Mekanika Teknik. Derajat hubungan yang baik antara variabel $X$ dengan variabel $Y$, juga dapat dilihat dari persamaan garis Regresi Linier yaitu $\hat{Y}=-0,32+1,03 X$ yang merupakan persamaan garis regresi yang signifikan dan merupakan garis regresi yang linier, serta setiap kenaikan satu skor Nilai Ujian Nasional Matematika di SMP dapat menyebabkan kenaikan skor hasil belajar Mekanika Teknik (Y) sebesar 1,03 pada konstanta $-0,32$.

Di dalam Nilai Ujian Nasional Matematika banyak dibahas tentang perbandingan, phytagoras, operasi persamaan linier satu variabel, operasi bilangan berpangkat, bentuk akar dan operasi tambah, kurang, kali, bagi pada bilangan. Sedangkan dalam mengerjakan soal mata pelajaran Mekanika Teknik juga lebih banyak membahas tentang hal tersebut, sehingga kemampuan yang dimiliki oleh siswa dalam Matematika mempunyai relevansi terhadap hasil belajar 
Mekanika Teknik. Hal ini sesuai dengan teori yang dikemukakan oleh Eka (2009) bahwa konsep serta penurunan rumus-rumus Matematika perlu dipahami dengan baik karena sebagian besar materi dalam Mekanika Teknik menggunakan perhitungan Matematika. Dan kajian ini selaras dengan kajian terdahulu dari Dedi Hariyanto (2011) yang mengatakan terdapat hubungan positif antara kemandirian belajar terhadap hasil belajar Mekanika Teknik II. Kajian dari Manik Suryati (2006) yang mengatakan terdapat hubungan positif antara nilai Matematika dengan Gambar Proyeksi, serta kajian dari Casmun (2002) yang mengatakan adanya hubungan antara Nilai Ebtanas Murni Matematika dengan hasil belajar Perhitungan Dasar Konstruksi Mesin.

\section{KESIMPULAN}

Dari hasil penelitian dan pembahasan, maka dapat disimpulkan bahwa:

1. Terdapat hubungan antara NUN mata pelajaran Matematika SMP dengan hasil belajar Mekanika Teknik.

2. Hasil perhitungan koefisien korelasi membuktikan bahwa siswa yang memperoleh NUN Matematika SMP yang tinggi cenderung mendapat nilai yang tinggi pula pada mata pelajaran Mekanika Teknik di SMK.

3. Kemampuan siswa yang kurang dalam Matematika maka mengakibatkan rendahnya nilai Mekanika Teknik yang diperoleh, dikarenakan dalam Mekanika
Teknik banyak menggunakan konsep perhitungan Matematika.

\section{Saran}

Dari hasil penelitian ini maka diberikan saransaran sebagai berikut:

1. Bagi siswa hendaknya melatih kemampuan dalam menyelesaikan soal-soal yang terkait dengan Mekanika Teknik.

2. Hendaknya guru memberikan bimbingan belajar kepada sisswa yang mengalami kesulitan dalam pelajaran Mekanika Teknik.

3. Bagi guru hendaknya mengulangi materi Matematika SMP yang berhubungan dengan mata pelajaran Mekanika Teknik agar siswa lebih mudah memahami materi yang diajarkan.

\section{DAFTAR PUSTAKA}

Anonim. 2014. Pengertian Ujian Akhir Nasional. http://referensimakalah.com. [16 Agustus 2014].

Arikunto, Suharsimi. 2009. Dasar-dasar Evaluasi Pendidikan. Jakarta: PT.Bumi Aksara.

Bahrudin, Enjah, Kartiwa. 2010. Persiapan Menghadapi Ujian Nasional SMP. Jakarta: PT. Epsilon Group.

Casmun. 2002. Hubungan antara Nilai Ebtanas Murni Matematika dengan Hasil Belajar Perhitungan Dasar Konstruksi Mesin di SMK Kemala Bhayangkari 1 Jakarta [skripsi]. Jakarta: Fakultas Teknik, Universitas Negeri Jakarta. 
Dimyati dan Mudjiono. 2002. Belajar dan Pembelajaran. Jakarta: PT. Asdi Mahasatya.

Hamalik, Oemar. 2005. Perencanaan Pengajaran Berdasarkan Pendekatan Sistem. Jakarta: PT.Bumi Aksara.

Hariyanto, Dedi. 2011. Hubungan Kemandirian Belajar Terhadap Hasil Belajar Mekanika Teknik II pada Mahasiswa Program Studi Pendidikan Teknik Bangunan Universitas Negeri Jakarta [skripsi]. Jakarta: Fakultas Teknik, Universitas Negeri Jakarta.

Hartini, Nara. 2010. Teori Belajar dan Pembelajaran. Bogor: Ghalia Indonesia.

Himitsu. 2014. Definisi Hasil Belajar Menurut Para Ahli. http://himitsuqalbu.wordpress.com. Agustus 2014.

Kementrian Pendidikan. 2006. Ujian Nasional. Jakarta: Menteri Pendidikan Nasional Republik Indonesia.

Lasriany, Netty. 2013. Fungsi Pembelajaran Matematika. http:// nettylasriany.wordpress.com. Juni 2014.

Mulyasa, E. 2008. Implementasi Kurikulum 2004 Panduan Pembelajaran KBK. Bandung: Remaja Rosdakarya.

Murtinugraha, Eka. 2009. Gaya Belajar dan Index Of Learning Styles (ILS) Mahasiswa Pada Mata Kuliah MT 1 di Jurusan Teknik Sipil FT UNJ. Jakarta: Fakultas Teknik, Universitas Negeri Jakarta.
Ngalim, Purwanto. 2009. Prinsip-prinsip dan Teknik Evaluasi Pengajaran. Bandung: Remaja Rosdakarya.

Purwanto. 2011. Evaluasi Hasil Belajar. Yogyakarta: Pustaka Pelajar.

Sekolah Menengah Kejuruan Negeri 35. 2013. Silabus Mata Pelajaran Mekanika Teknik. Jakarta: Departemen Pendidikan dan Kebudayaan.

Sekolah Menengah Kejuruan Negeri 335. 2013. Kompetensi Inti dan Kompetensi Dasar. Jakarta: Departemen Pendidikan dan Kebudayaan.

Sudjana. 2005. Metoda Statistika. Bandung: 2005.

Sudjana, Nana. 2011. Penilaian Hasil Proses Belajar Mengajar. Jakarta: PT.Remaja Rosdakarya.

Suherman dan Bahrudin. 2011. Matematika. Bandung: Epsilon Group.

Sujono. 1988. Matematika. Jakarta: P2LPTK.

Sukardi. 2011. Metodologi Penelitian Pendidikan. Yogyakarta: PT.Bumi Aksara.

Suryati, Manik. 2006. Hubungan Nilai Matematika Ujian Nasional SLTP terhadap Hasil Belajar Gambar Proyeksi pada Siswa Kelas XI IPA di SMA Negeri 39 Cijantung Jakarta Timur [skripsi]. Jakarta: Fakultas Bahasa dan Seni, Universitas Negeri Jakarta.

Tony. 2006. Statika. Jakarta: Erlangga. [Anonim]. 2014. Ceramics Industry. http://streerdirectory.co.id. Maret 2014. 